what may be the significance of these abnormal individuals of Aphis aceris deprived of the faculty of reproduction.

Applying to these insects my theory of the biological evolution of the Aphides, this third phase must also be a pseudogyne, and by following it patiently I could not but succeed in obtaining sexual individuals. 'This has been the case, but not so quickly as I expected.

At first the Aphides, which resembled their progenitor, increased in size normally ; in twenty days they produced broods of embryos furnished with long hairs, exactly like those which I had obtained in the preceding brood. The forms with leaflets, observed by the entomologists of Paris and the north, were wanting here at Montpellier, upon the maple that I observed. But after the end of May or the first days of June, all the normal forms had disappeared, and I had left only embryos collected in groups upon the leaves, as figured by Réaumur in the third volume of his ' Mémoires.'

June, July, and August passed without my nurselings increasing in size or moving; at the beginning of September the leaves began to fall, which became troublesome in the pursuit of my observations. Fortunately I observed that when the fallen leaf ceased to furnish them with nourishment, my little animals were well able to quit it and seek their fortune elsewhere. I profited by this observation to transfer these embryos from a yellow to a green leaf, fastening with a pin the withered leaf to the fresh one. In a few hours all my Aphides were attached to the latter.

By this means I had the pleasure, on the 12th September, of seeing the skin of these hairy embryos split and again furnish me with an Aphis of normal form and of a uniform light yellow colour, which grew very quickly, and began, in the first days of October, to produce young of different dimensions. Smaller and more elongated than any of their predecessors, these insects, which were at first green, but afterwards became blackish brown, ran over the branches of the maple, and showed that I had before me the two sexes, for the copulations were frequent, the same male evidently fecundating several females.

But this is not all. Pushing polymorphism to the extreme point, I saw among numerous apterous males some which were winged, and just as we have seen the second phase composed of emigrant pseudogynes partly winged and partly apterous, we witness here a production of apterous males to fecundate the females upon the same tree, and of winged males which can go to a distance in search of females which have fallen down or the wind has carried away.

Soon after copulation the female deposits her ova under the buds or in the fissures of the bark of the maples; they are at first light yellow, but soon become bright shining black. These are the ova which hatch in the spring and furnish the foundress pseudogyne of the colony.-Comptes Rendus, November 10, 1884, p. 819 .

Urnatella gracilis.

Prof. Leidy remarked that Mr. E. Potts had given to him, in 
October 1583, a fragment of a tree-branch on which were many groups of Urnatella. The fragment, 3 inches by $\frac{1}{3}$ of an inch, was obtained in the fore bay at Fairmount. Around its middle, for about an inch in length, there were thirty separate groups of Urnatella, in nearly all consisting each of two stems, of unequal length, and devoid of terminal polyps. The stems diverged and curved downward and were quiescent, but were evidently living, as they exhibited slight sensitiveness to disturbance. The specimen was placed in an aquarium, exposed to the north light of a window, and in this position, at the moderate temperature of usual livingrooms, was kept during the winter. In March, the stems were observed all to have dereloped polyps at the distal end, in which condition they continue at the present time (April). Most stems are terminated by a single polyp, but a few exhibit a smaller polyp, supported on a cylindrical joint springing from the antepenultimate joint of the stem, including the terminal polyp. The stems are quite irritable and bend in graceful curves from each other on the slightest disturbance. The longer stems even hang their heads in a single spiral turn. The longest stems consist of a dozen joints and measure about one eighth of an inch. The shortest stems exhibit one third the number of joints. The stems appear alternately white and black, the former colour corresponding with the thicker portion of the joints, the latter with the constricted portions. Many of the mature joints exhibit traces of the cup-like rémains of attachment of branches, in most cases on one side only.

These specimens appear to indicate that, as in the other freshwater Polyzoa, the polyps die on the approach of winter; but the headless stems appear to remain, securely anchored, and ready to reproduce the polyps in the spring. If portions of the stem are destroyed, the remaining joints are capable of reproducing the polyps, commonly from the summit of the terminal joint. Branches usually spring from the last one or two joints, newly produced from that which immediately supports the terminal polyp. Specimens also show that heads may start laterally from old or mature joints. Thus the latter appear to serve as the statoblasts of other freshwater Polyzoa, but ordinarily they do not become isolated from one another. As no specimens have been seen with stems consisting of more than a dozen joints, perhaps, after reaching this condition, the polyps become detached, to establish new groups.-Proc. Acad. Nat. Sci. Philad., Nov. 18, 1884, p. 282.

\section{Note on the Intelligence of a Cricket parasitized by a Gordius.}

Dr. Henry C. McCook said that some remarks upon the habits of the cricket published by him had called forth an interesting communication from Mrs. C. W. Conger, of Groton, New York, the substance of which is as follows:-

"Some twenty-four years ago my husband and myself took 


\section{$2 \mathrm{BHL}$ Biodiversity Heritage Library}

1885. "Urnatella gracilis." The Annals and magazine of natural history; zoology, botany, and geology 15, 274-275. https://doi.org/10.1080/00222938509459331.

View This Item Online: https://www.biodiversitylibrary.org/item/53785

DOI: https://doi.org/10.1080/00222938509459331

Permalink: https://www.biodiversitylibrary.org/partpdf/53207

\section{Holding Institution}

Smithsonian Libraries

\section{Sponsored by}

Smithsonian

\section{Copyright \& Reuse}

Copyright Status: Public domain. The BHL considers that this work is no longer under copyright protection.

This document was created from content at the Biodiversity Heritage Library, the world's largest open access digital library for biodiversity literature and archives. Visit BHL at https://www.biodiversitylibrary.org. 